\title{
Verseëling met die Heilige Gees as element in die kerklike kategese: Basisteoretiese perspektiewe
}

C J H Venter \& C N van der Merwe

(Noordwes-Universiteit, Potchefstroomkampus)

\section{ABSTRACT}

\section{Sealing of the Holy Spirit as element in ecclesiastical catechesis: Basis-theoretical perspectives}

Too often the emphasis in catechetic instruction falls on objective cognitive content. This aspect of instruction should rather be complemented by ascertaining whether young catechumens subjectively internalise God's salvation and grace and make it their own by living out their confessed faith in concrete deeds of faith. The point of departure in catechetic instruction should be that the sealing of the Spirit is primarily an act of God, guaranteeing catechumens that the Spirit's indwelling presence is a guarantee of an ultimate and final inheritance. This promise and guarantee should be repeatedly communicated in catechetic instruction by inter alia highlighting the embedded and related meanings of the concept "sealing". In addition related concepts complementary to "sealing" should be discussed. The process of instruction should also concentrate on explaining these concepts by applying concrete language and images on the cognitive level of children and young adults.

\section{ORIËNTERING}

Vir die doeleindes van hierdie artikel is resente navorsing wat fokus op aspekte van die kerklike kategese en jeugsorg geraadpleeg en, afgesien van toepaslike literatuurstudie, is ook die resultate van empiriese navorsing nagegaan (vgl Prins 2001; Dreyer 2003:109; Van der Merwe 2004:408-9). Die empiriese werk omvat 'n wye terrein van die kerklike kategese en jeugsorg. Twee van die aspekte wat in bogenoemde ondersoeke besonder sterk na vore gekom het, kan as nadere motive-ring vir die navorsing in hierdie artikel beskou word. Die eerste is die bevinding dat ' $n$ groot aantal jongmense nadat hulle belydenis van geloof afgelê het - van die kerk verwyderd raak of by ' $n$ ander kerk aansluit of in hulle geloofslewe verflou. "Die feit van die saak is dat jongmense wegraak ... en dat daar by heelwat 'n totale verwydering van die kerk is" (Dreyer 2003:109). Van der Merwe (2004:408) beklemtoon dieselfde saak as hy stel: 
"Dit lyk of die jong belydende lidmate dikwels kort na belydenisaflegging die binding met die kerk kwytraak en geen belangstelling vir kerklike aktiwiteite toon nie en moeilik tot meelewendheid met die kerk beweeg kan word" (Vergelyk ook Prins [2001:13-34] in hierdie verband). Die tweede bevinding van belang vir hierdie navorsing is dat nie net heelwat jongmense los raak van die kerk nie, maar ook dat die geloof wat hulle bely het, nie oorgaan in geloofsdade nie. Die moontlike oorsaak hiervan is dat jongmense dalk nie die erns van belydenisaflegging besef nie of dat dit maar net nog ' $n$ proses is (soos ' $n$ prysuitdeling) waardeur hulle moet gaan vanweë die druk van hulle gesin en familie (vgl Dreyer 2003:109110).

Bogenoemde bevindinge roep verskillende vrae op: Is die aanbiedingswyse en aard van die kategese en belydenisaflegging nie dalk te intellektualisties nie? Word daar in die kategese nie bloot objektief en met die klem op feitekennis alleen met die Woord van God omgegaan nie? Veroorsaak die beklemtoning van feitekennis nie dat dalk selde tot subjektiewe toe-eiening en belewing van heilswaarhede en van die leer van die kerk gekom word nie? Word leerstukke nie beskou en aangebied as stukke leer nie? 'n Relevante vraag is ook of die invloed van die postmodernisme, spesifiek dan die siening dat daar plek is vir baie godsdienste in ons samelewing, en die beklemtoning dat godsdiens veral 'n saak van ervaring is, nie 'n rol speel in die besluit van jongmense om die kerk te verlaat nie?

Per definisie hou geloof en die belydenis van geloof elemente in soos vastigheid, sekerheid, die bevestig en gevestig wees in die waarheid en die oortuiging van 'n toekoms. In sodanige begrippe word geloof immers in gereformeerde belydenisskrifte verwoord. ' $n$ Bepaalde uitdrukking wat in besonder in Paulus se Briewe gebruik word om sekerheid en vastigheid in die geloofslewe aan te dui is verseël met die Heilige Gees.

Die doel met hierdie artikel is om hierdie uitdrukking en enkele verbandhoudende begrippe op basisteoretiese vlak van nader te ondersoek - spesifiek as element in die kerklike kategese. Die mikpunt is om sodoende opnuut te probeer ontgin wat ten grondslag lê aan die aspekte van sekerheid en vastigheid in die kerklike kategese, juis met die oog op die onderrig daarvan in die kerklike kategese en op die persoonlike toe-eiening daarvan deur die katkisant. 


\section{BASISTEORETIESE PERSPEKTIEWE OP DIE BEGRIP "VERSEËLING MET DIE HEILIGE GEES"}

\subsection{Algemene gebruiksvelde van verseël in die tyd van die Nuwe Testament}

Van der Merwe (2004:226) toon aan dat die begrip verseël verskillende algemene het:

\section{Beskerming}

In die vroegste tye is ' $n$ amulet verseël om te verhoed dat enigeen daarmee peuter. Magiese krag is geassosieer met 'n seël - iemand wat die seël sou breek, het gevrees dat iets ernstigs met hom sal gebeur. As die seël nie gebreek is nie, was dit die waarborg dat niks met jou sal gebeur nie. Daniël word byvoorbeeld in die leeukuil verseël (Dan 6:18), wat as waarborg moet dien dat niemand hom sal kan help nie. So ook word die graf van Jesus verseël om te verseker dat niemand sy liggaam uit die graf sal kan verwyder nie (Matt 27:66).

\section{Bewys van eienaarskap}

Die seël is op artikels gebruik om die eienaarskap daarvan te bewys. Benewens die metaforiese gebruik van die woord seël en die werkwoord verseël het hierdie woorde ook 'n direkte en konkrete betekenisvlak: seël en verseël het ook onder andere die volgende betekenisnuanses: die voorstelling van 'n kenteken, 'n merk, 'n brandmerk of 'n inkerwing wat op slawe aangebring is om hulle as eiendom van 'n eienaar te waarmerk (Floor 1979:83). So 'n verseëling was bedoel as beskerming sodat die slaaf nie van sy eienaar vervreem of geroof kan word nie. In Romeine 4:11 word die besnydenis so 'n teken en 'n seël genoem.

\section{Die egtheid van dokumente}

Die mees algemene gebruik van verseëling was om die oorspronklikheid en juistheid van dokumente te waarborg. Juda gee byvoorbeeld aan Tamar sy seëlring as waarborg (Gen 38:18) en Potifar gee sy seëlring aan Josef as sigbare teken dat hy die huislike gesag aan Josef oordra (Gen 41:42; vgl. ook Jer 32:10-14; 1 Kon 21:8-13, Neh 9:28; Neh 10:1; Est 8:8).

\section{Handelsmerk}

Seëls is gebruik as 'n metode om 'n handelsmerk aan te bring. Hierdie tipe handelsmerk is veral op kleipotte aangebring. 


\section{Ritueel}

Volgens Huey (1975:3220 is seëls ook gebruik "in community rites especially in the annual New Year Festival when the kings of Assyria and Babylonia sought the blessing of the gods in prosperity for the nation". Van't Spijker (1989:355) stel dat verseël veral die betekenis het van 'n eiendomsmerk; verseël impliseer die funksie om iets te bedek vir 'n ander; dit dui aan dat 'n waardevolle artikel ongeskonde bewaar sal word en verseker dat iemand deel het aan ' $n$ bepaalde saak.

Die saak van verseëling was vir die mense in die tyd van die Bybel dus nie iets vreemds nie, want dit was 'n praktiese gebruik oor 'n wye spektrum van die lewe. Ten opsigte van die uitdrukking "verseëling met die Heilige Gees" word dus by 'n bekende praktyk van verseëling aangesluit.

\subsection{Voorkoms van die uitdrukking "verseël met die Heilige Gees" in die Briewe van Paulus}

Bogenoemde stelwyse kom vier keer voor in die Briewe van Paulus:

- 2 Korintiërs 1:22: “... wat ons ook verseël het”;

- $\quad 2$ Korintiërs 5:5: “... wat ons ook die Gees as onderpand gegee het";

- Efesiërs 1:13: “...verseël is met die Heilige Gees van die belofte";

- Efesiërs 4:30: “...deur wie julle verseël is tot die dag van verlossing.

Met die oog op basisteoretiese teorievorming sal aandag veral gewy word aan 2 Korintiërs 1:21 en 22, en Efesiërs 1:13 en 4:30. Die motivering hiervoor is dat die begrip verseël in albei gedeeltes voorkom en verder dat begrippe wat sterk verband hou met verseël, saamgegroepeerd in 2 Korintiërs 1:21-22 voorkom (vgl CampbellLane 2003:48).

\section{3 "Verseël met die Heilige Gees" - 'n dieptesnit uit 2 Korintiërs 1:21-22}

Vervolgens word eksegeties aandag geskenk aan dié gedeeltes in die Briewe van Paulus waarin die saak van die verseëling met die Heilige Gees voorkom, naamlik 2 Korintiërs 1:21-22 en Efesiërs 1:3-14 en 4:30. 
Die gedeelte 2 Korintiërs 1:21-22 kom voor in die perikoop wat strek van 1:12-22. Hierin handel Paulus oor sy planne en voornemens. In vers 17 is daar 'n moontlike breuk omdat die sin begin met dan wat as merker kan dien vir 'n oorgang tussen die weergawe van die gewoon menslike planne van Paulus (v 12-17) en dit wat God vir hom bepaal (v 18-22). Die saak van die verseëling met die Heilige Gees val in dié gedeelte waarin die optrede van God beskryf word (v 17-22).

Die keuse val op 2 Korintiërs 1:21 en 22 om as dieptesnit te bestudeer, omdat die begrip verseël nie geïsoleerd voorkom in verse 21 en 22 nie. Drie ander begrippe wat sterk verband hou met verseël, en wat vooraf in berekening gebring moet word in die uiteensetting van die betekenis en inhoud van verseël, is die volgende: die begrippe bevestig (bebaioon), salf (chrisas) en waarborg (arraboon) wat in 2 Korintiërs 1:21 en 22 saam met verseël gebruik word. Dit is wenslik dat vooraf aan hierdie drie begrippe aandag gegee word. Terwille van vergelyking en kontrastering is dit wenslik om aandag te gee aan hierdie drie begrippe om die inhoud van die begrip verseël hierin nader te bepaal.

\subsubsection{Die begrip "bevestig” in 2 Korintiërs 1:21}

"Maar Hy wat ons saam met julle bevestig in Christus en ons gesalf het, is God" (2 Kor 1:21). Bevestig in genoemde vers staan in die praesensvorm wat dui op 'n voortdurende proses. Binne die konteks van vers 21 beteken dit 'n lewenslange proses van vestig, om iets vas en seker te maak. Louw en Nida $(1988 b: 340)$ toon ook die verdere betekenisnuanses van bevestig aan as "confirm", "establish", "make good". Volgens Song (1998:178) veroorsaak dié begrip by iemand "to be firm or established in belief" (vgl in dié verband ook Garland 1999:105).

In vers 21 hang die betekenis van die praesens partisipium bevestig saam met die betekenis van in Christus: "This could refer to the believer's incorporation into Christ, as a member of the body of Christ, and to be firm would allude to the continual securing of the relationship to Christ" (Song 1998:178). Die "bevestig-wees in Christus" kan egter bloot 'n objektiewe gebeure met weinig of geen subjektiewe resultate wees as gelowiges nie heilstoeëienend daarmee te werk gaan nie (Lotter 1993:38). Die bevestig-wees in Christus het 'n objektiewe oorsprong, maar ook 'n subjektiewe element; 'n effek in die mens. Die heil begin buite die gelowige as 'n daad van God 
(objektief), maar word voortgesit en uitgewerk binne die gelowige as voortdurende handeling van God en as heilsbelewing aan die kant van die gelowige (subjektief). Dit gaan derhalwe ook om die subjektiewe heilstoeëiening en heilsbelewing (Lotter 1993:38; Bruner 1970:271).

\section{Bevinding vir die kategese:}

In die kategese het 'n verbondskind te doen met inbegrepenheid in Christus, 'n saak wat vas en seker is en lewenslank vas en seker sal bly. Die gawe van heil aan die katkisant is gerig op toe-eiening deur die katkisant.

\subsubsection{Die begrip "salwing" in 2 Korintiërs 1:21}

"Maar Hy wat ons saam met julle bevestig in Christus en ons gesalf het, is God". Ná bevestig, wat in die praesens staan en voortgaande handeling aandui, is die daaropvolgende werkwoorde in vers 21-22 ("verseël" en "in ons harte gegee") aoristus partisipia wat 'n eenmalige gebeurtenis aandui. Die begrip salf is ' $n$ bekende saak in die Woord van God. Op verskillende plekke kom ons die begrip salwing in sowel die Ou as die Nuwe Testament teë. Die simboliese handeling van salwing is bekend in die Ou Testament: profete, priesters en konings is deur salwing aangewys, afgesonder en op betekenisvolle manier bekwaam gemaak vir hulle amp. In die $\mathrm{Ou}$ Testament dui salwing op die ontvang van besondere gawes om opdragte van die Here uit te voer: dink in hierdie verband aan Saul (1 Sam 10:1-10); Dawid (1 Sam 16:13); Salomo (1 Kon 1:39); Jehu (2 Kon 9:6).

Jesus Christus is ook gesalf "tot ons hoogste Profeet en Leraar, ons enigste Hoëpriester en ons ewige Koning" (Matt 3:16-17). Salwing dui besonderlik op toerusting met die Heilige Gees. In die Nuwe Testament is daar eintlik net een gesalfde, naamlik Christus wat deur God afgesonder en bekwaam gemaak is as Verlosser tydens die salwing met sy doop. Hiertydens het Christus die Heilige Gees in sy volheid ontvang. Dit is ook opvallend hoe die verseëling met die Heilige Gees in 2 Korintiërs 1:21-22 verbind word aan die salwing met die Heilige Gees.

In 2 Korintiërs 1:21-22 kom besonder sterk trinitariese elemente na vore - veral wanneer gehandel word oor die salwing (Lotter 1993:42). In hierdie teksverse is sprake van die Vader wat die gelowiges bevestig in Christus die Gesalfde; van Christus, die 
Gesalfde, die Seun van God, wat ook betrokke is by die salwing van die gelowige. Dit wat daarop volg, is ' $n$ verdere uitbou van wat God doen deur middel van Christus en die Heilige Gees.

\section{Salwing as toerusting}

Vroeër is gestel dat Christus met sy salwing deur die Heilige Gees toegerus is vir sy verlossingstaak. Louw en Nida (1988b 484) toon aan dat salwing hoofsaaklik gebruik is vir die aanstelling of die bekwaammaking van iemand: "to assign a person to a task, with the implication of supernatural sanctions, blessings and endowment". Gelowiges word dus deur God met die Heilige Gees toegerus vir hulle belangrike taak as verlostes om hulle roeping in hierdie wêreld as God se kinders suksesvol te kan uitvoer. Salwing bring mee dat gelowiges God in hierdie wêreld bely, hom of haar aan God in die daaglikse lewe toewy en teen die sonde, die duiwel en sy ganse ryk stry. Van't Spijker (1989:416) beskryf dié toerusting deur die Heilige Gees soos volg:

Daartoe moest het komen! Immers een mens leeft niet zonder godsdienst, hij leeft wel zonder God in de wêreld. En waar de Geest in ons leven, de dinge van God tot een werklijkheid maakt, daar gaan wij God zelf missen, daar gaan we ook zelf God zoeken. En daar zal God zichzelf aan ons openbaren, zodat we niet alleen te maken hebben met een eeuwige liefde der verkiezing, nie alleen ook met een eeuwige liefde der verzoening, maar ook met een eeuwige liefde die zich openbaart in de heiliging.

In die Heidelbergse Kategismus word met die woord heiligmaking die volledige werk van God die Heilige Gees aangedui. Deur die salwing word ons dus inderdaad deelgenote van Christus deur die Gees.

Behalwe die toerusting vir die taak van 'n gelowige tot 'n heilige lewe, het die salwing ook betrekking op toerusting deur verdieping in insig en geestelike kennis. In Jesaja 11:1-3 word die salwing van die messiaanse koning profeties beskrywe (Floor, 1979:12). Die toerusting met die Heilige Gees word dan in drie begrippepare nader geteken:

- Die Gees van wysheid en verstand (v 2a).

- $\quad$ Die Gees van raad en sterkte (v 2b).

- $\quad$ Die Gees van kennis en die vrees vir die Here (v 2c). 
Lotter (1993:43) stel dat gelowiges na salwing 'n dieper kennis besit, die vermoë om geestelik te kan onderskei waarop dit aankom (1 Kor 2:15; Rom. 12:2).

\section{Bevinding vir die kategese}

Salwing as element in die kategese het betrekking op die toerusting van 'n katkisant tot 'n lewe van heiligmaking en dui op die verdieping van kennis en insig om geestelike waarhede te kan onderskei.

\subsubsection{Betekenis van die begrip "verseël" in 2 Korintiërs 1:21-22}

Die algemene gebruiksvelde van die begrip verseël in die wyer verband van die Nuwe Testament is reeds vroeër aangetoon. In hierdie onderafdeling gaan dit om die nadere aanduiding en uiteensetting van die betekenis van die begrip verseël in 2 Korintiërs 1:21 en 22 en ook in Efesiërs 1:13-14 en 4:30.

Louw en Nida (1988b:568) dui die betekenis van verseël in genoemde gedeeltes aan as "to use a seal, to close, to make something secure, to seal, to put a seal on". Die selfstandige naamwoord dui volgens Louw en Nida (1998b:568) op "an engraved object used to make a mark denoting ownership, approval or closure of something (normally done by pressing into heated wax and usually attached to a document or letter) - seal, signet". Om dokumente te verseël was 'n algemene gebruik in antieke tye.

Dit is redelik om uit die uiteensetting hierbo af te lei dat "verseël" in 2 Korintiërs 1:21-22 en Efesiërs 1:13 en 4:30 gebruik word in drieërlei sin, naamlik eienaarskap; om iets te waarmerk en om iets of iemand veilig te bewaar. Hierdie drie betekenisse word vervolgens kortliks omlyn insoverre dit toepaslik is vir die tema van hierdie artikel.

\subsubsection{Die betekenis van eienaarskap}

Christus het die gelowiges met sy bloed gekoop (Heb 9:12). Deur hierdie koopaksie behoort die gelowiges aan God en is Hy hulle Eienaar. "Dit is nou die taak van die Heilige Gees om hierdie eienaarskap van die kind van God aan hom/haar te beseël, dit wil sê in te prent dat dit so is en verder te oortuig dat dit so is" (Lotter, 1993:47). Die Satan het nie vrede met hierdie toestand nie. Hy wil die gelowiges onseker maak en laat twyfel of hulle aan God behoort. Daarom is die verseëling met die Heilige Gees ' $\mathrm{n}$ voortgaande proses. Gelowiges moet oortuig word dat hulle met die kosbare 
bloed van hulle Verlosser en Saligmaker, Jesus Christus, vir eens en vir altyd gekoop is. So impliseer die werk van die Heilige Gees die merk van die eiendomsreg wat die Vader op hulle plaas. In 2 Timoteus 2:19 is 'n bevestiging van die gedagte van eienaarskap: "Ewenwel, die fondament van God staan vas met hierdie seël." Dit is met die Heilige Gees van die belofte dat die gelowiges verseël is. Vergelyk in hierdie verband Efesiërs 1:13 en ook Song (1998:180): "...and as God's promise carries with it the absolute certainty of fulfilment, they are preserved under the seal of the Holy Spirit inviolate unto the day of redemption".

Die werkwoord verseël is dus in die eerste plek bedoel as 'n eiendomsterm, naamlik om aan te toon dat die lesers van die brief gelowiges uit die heidendom op grond van die ontvang van die beloofde Gees - nou God se eiendom is en nie meer aan die Satan nie behoort nie. Die Gees is hierdie gelowiges se eiendomsbewys. Die Gees as seël verseker die gelowiges dat hulle God se eiendom is en deel het aan Christus en sy verlossing. Deur die verseëling met die Heilige Gees gee God aan die gelowiges in Efese ook die stempel dat hulle, net soos alle ander gelowiges uit die Jodedom en heidendom, sy eiendom is (vgl. Garland 1999:106). Verseëling met die Heilige Gees, salwing met die Heilige Gees, toegerus met die Heilige Gees as onderpand - dit is alles uitdrukkings wat wys op die rykdom van die werk van die Heilige Gees in die gelowige.

\section{Bevinding vir die kategese}

Die begrip verseël beklemtoon vir die katkisant die feit en konkrete werklikheid dat God sy eienaar is en dus in beheer is van alle fasette van sy lewe.

\subsubsection{Die betekenis van 'n waarmerk}

Om iets te waarmerk is 'n aktiwiteit wat vandag bekend is. As iemand 'n CV vir 'n werksaansoek voorberei, moet die fotokopieë of afskrifte van dokumente gewaarmerk word om te bewys dat dit 'n juiste kopie van die oorspronklike is. Om iets te waarmerk is om die egtheid daarvan te bevestig, om te bevestig dat die kopie presies ooreenstem met die oorspronklike dokument. Die afskrif word as waar gesertifiseer. Dit is ook ' $n$ betekenisvlak wat na vore kom in die saak van die verseëling met die Heilige Gees. Die Heilige Gees verseël, sertifiseer, bevestig dat die kindskap van die gelowige eg en waar is. God gee die Heilige Gees as 'n seël aan die gelowige waardeur as't ware op die gelowige geskrywe is: oorspronklik, eg, 
waar: "Dis 'n belangrike funksie wat die Heilige Gees hier verrig: om herhaaldelik die gelowiges 'in te prent' dat hulle egte Christene is en nie nabootsings is of mense wat nie kompleet is nie, asof daar nog iets moet bykom" (Lotter 1993:48).

By die wedergeboorte is die Christen volledig kind van God en is die verseëling (inprenting, sertifisering) die waarmerk dat so 'n persoon kompleet in Christus is en dat daar nie nog iets ontbreek nie. Lotter (1993:48-49) gebruik die metafoor van 'n baba: wanneer 'n baba gebore is, besit hy/sy alle liggaamsdele wat, net soos by 'n volwasse mens, teenwoordig is, al is dit nog nie ontwikkel en volgroeid nie. Niemand sal kan sê dat die baba nie volledig mens is nie, net omdat die armpies dun is of die verstandelike vermoëns nog nie ontwikkel is nie.

Verseëling is die werk van God alleen. Van die mens kan daar geen aktiwiteit in hierdie opsig uitgaan nie. Die mens is die ontvanger van die verseëling (Muddiman 2001:79). Die mens moet God se evangelie van verseëling met die Heilige Gees glo en dit daardeur sy eie maak. Aan die verseëling as sodanig kan die mens niks doen nie.

\section{Bevinding vir die kategese}

Verseëling bied aan die katkisant die bewys dat sy kindskap oorspronklik en eg is en dat hy as sodanig gewaarmerk is deur die Heilige Gees.

\subsubsection{Die betekenis van veilige bewaring}

'n Volgende betekenis van verseël dui op veilige bewaring met die oog op die toekoms, dit wil sê bewaring om veilig oor te bring by die eindbestemming (vgl Thrall 2000:137). Die verseëling met die Heilige Gees verdryf al die vrese vir die toekoms. Die gelowige kan hom onder alle omstandighede veilig voel by God. Alle vrese vir die toekoms word met die verseëling met die Heilige Gees verdryf en die gelowige kan die toekomspad doelgerig stap.

\section{Bevinding vir die kategese}

' $n$ Katkisant hoef nie te twyfel oor die ewige lewe nie, omdat die Heilige Gees hom veilig bewaar en veilig sal laat tuiskom.

\subsubsection{Die inhoud van die verseëling deur die Heilige Gees}

Lotter (1993:46) haal Winslow (1984:223) se definisie van die inhoud van verseëling aan: 
"It is the act of the Holy Spirit by which the work of grace is deepened in the heart of the believer, so that he has an increasing and abiding conviction of the acceptance in Jesus, and his adoption into the family of God. It is a clearer and more undoubted manifestation of Christ to the soul, a larger degree of the sanctifying, witnessing and anointing influences of the Holy Ghost, evidencing itself in a growing holiness of character".

Reymond (1998:767) formuleer die aspek van verseëling só:

"The sealing of the Spirit, to be distinguished from the baptism of the Spirit and the filling of the Spirit, is that act of God, performed in connection with his act of adoption, whereby he seals the believer to the final day of redemption by the indwelling presence of the Spirit of adoption, whose indwelling is the guaranteeing 'down payment' of the Christian's full and final inheritance".

Salwing en verseëling moet egter nie met mekaar verwar word nie, want hulle is nie dieselfde nie. Salwing en verseëling is wel albei aktiwiteite van die Heilige Gees, maar is in wese verskillend met uiteenlopende vertrek- en doelpunte. In die samehang van salwing en verseëling word ons opmerksaam gemaak vir wat Paulus in 2 Korintiërs 1:21-22 skryf: "Maar Hy wat ons saam met julle bevestig in Christus en ons gesalf het, is God wat ons ook verseël het en die Gees as onderpand in ons harte gegee het". Dit is opmerklik dat verseëling met die Heilige Gees verbind word aan salwing met die Heilige Gees. Deur salwing word 'n mens - deur die Heilige Gees deelgenoot van Christus. Oor verseëling en salwing merk Van't Spijker (1989:422) die volgende op:

"De verzegeling is aanduiding van hetzelfde met dien verstande, dat zowel de zalving als de verzegeling wijzen op een deelgenootschap aan Christus en al zijn weldaden. Slechts op die manier zijn wij in het oog van God gekenmerkt als zijn eigendom: in Christus en door zijn Geest".

Ons kan dus sê dat 'n ware Christen, dit wil sê iemand wat deur die Heilige Gees tot profeet, priester en koning afgesonder is in God se diens, die kenmerk dra van die eiendomsreg wat God op hom het. Salwing is 'n tipiese eiendomskenmerk wat voortvloei uit die verordening of afsondering tot 'n amp of diens, terwyl dit beteken dat jy tot hierdie diens bekwaam gemaak word 


\section{Bevinding vir die kategese}

Die besef en belewing van verseëling deur die Heilige Gees verdiep die sekerheid van God se genadewerk in die lewe van 'n katkisant en bring geborgenheid en verinniging in sy verhouding met God.

Verseëling deur die Heilige Gees moet voorts onderskei word van salwing deur die Heilige Gees. Deur salwing word 'n katkisant deelgenoot van Christus deur die Heilige Gees. Deur verseëling word die katkisant oortuig van die vastigheid en van die sekerheid van sy deelgenootskap in Christus.

\subsubsection{Die Heilige Gees as onderpand}

Die begrip onderpand is een van drie begrippe (bevestig, salf, onderpand) wat nou verband hou met verseël. Vervolgens word verdere aandag gewy aan die begrip onderpand wat voorkom in 2 Korintiërs 1:21-22, 2 Korintiërs 5:5 en Efesiërs 1:15. In al drie hierdie teksgedeeltes staan "onderpand" binne die gedeeltes waar die eskatologiese verwagting van die kerk behandel word, naamlik die beloofde heil, die beloofde erfenis en die verheerliking van die liggaam by die opstanding. As die Heilige Gees die onderpand genoem word, kom die gedagte van waarborg na vore. Die Gees as geborgde belofte wys wat ons in die toekoms nog meer van die Gees kan verwag. Ons hoef nie te twyfel nie, want ons sal die volle erfenis ontvang.

"Paul also called the Holy Spirit the 'guarantee'. He has put his seal upon us and given us his Spirit in our hearts as guarantee. When God gives his great salvation according to Paul's understanding, he not only gives it, he gives with it his guarantee that he has given it, and this is the the Holy Spirit".

(Brunner 1970:271)

Song (1998:181) wys daarop dat onderpand nie net die waarborg is nie, maar ook "the first down-payment by which he who makes it, assures the recipient of final payment in full". Die volle erfenis sal eendag uitgekeer word, maar as eerste paaiement ontvang ons reeds die gawe van die Heilige Gees. Hierdie belofte dui op die voorlopige van die heil van God, maar ook op op die sekere waarborg wat ons ontvang dat die volle bedrag, die volle erfenis eendag uitgekeer sal word. Wie met die Heilige Gees verseël is, het daarin 'n groot gawe ontvang. Hierdie gawe is egter nog 'n voorlopige, maar ook 'n gewaarborgde gawe; die volle erfenis is nog nie daar nie; die heil 
van die Here in al sy heerlikheid is nog uitstaande. Song (1998:181) stel die belofte op hierdie uitstaande heerlikheid soos volg: "The Spirit is therefore the gift given in the heart of the believers as the deposit or down-payment. The full payment will be something extra: the life of the resurrection". In Efesiërs 1:15 word die Gees beskryf as die waarborg in teenstelling tot die twyfel of ons wel ooit die erfenis van die verlossing sal ontvang.

\section{Bevinding vir die kategese}

Onderrig aan die katkisant dat die Gees die onderpand (eerste deposito) is van die volle gawe wat kom - en dat dieselfde Heilige Gees die volle som waarborg - bied sekerheid vir vandag en vir more. Uit môre se volle gawe bied God immers die Heilige Gees as die deposito vir vandag.

\subsubsection{Samevatting van resultate uit 2 Korintiërs 1:21-22}

Uit die voorafgaande verkenning blyk veral die volgende:

- Bevestig wys op die voortdurende sekuriteit in die gelowige se bestaan, want die daad van bevestiging is onveranderlik. Die uitdrukking saam met julle bevestig hou in dat die een wees met Christus steeds sal toeneem.

- $\quad$ Salwing, wat eenmalig plaasvind, hou in dat die gelowige deel het aan die koninklike voorregte as kind van God, ook in die tye wat kom. Ook word gelowiges sodoende toegerus vir hulle taak tot heiligmaking in hierdie wêreld. Vir hierdie taak ontvang hulle geestelike onderskeidingsvermoë.

- Die gedagte van verseëling bevestig dat gelowiges deur die Heilige Gees as eiendom van God gemerk is. Die gelowige dra die merkteken van God se eienaarskap. Die Heilige Gees as onderpand/waarborg wys vooruit na die eerste paaiement en beloof die volle som van die verlossing wat God in die harte van sy gelowige kinders gegee het. Die Heilige Gees waarborg voorts dat God wat hulle gesalf en verseël het, hulle veilig sal oorbring na hulle finale bestemming.

\section{BASISTEORETIESE PERSPEKTIEWE UIT EFESIËRS}

\section{1:3-14}

\subsection{Oriëntering}

Die lofprysing in Efesiërs 1:3-14 is één lang sin wat bestaan uit 12 verse, en dit is moeilik om "deze lofprijzing in kleinere delen te 
splitsen, want de lange zin is als een gouden keten waarvan de schakels onlosmakelijk aan elkaar verbonden zijn" (Floor 1995:43). Hierdie gedeelte is ' $n$ lofprysing van ongekende diepte en rykdom: "Op een verheven toon, wordt door Paulus bij wijze van spreken een hele dogmatiek ontvouwd" (Floor 1995:44), want Paulus skryf oor verkiesing, versoening, verlossing en verseëling.

Mouton (1987:82) maak die volgende verdeling van die perikoop Efesiërs 1:3-14. Die gestruktureerdheid van, en die rigtingwysers in die perikoop dui op God se handeling of seëninge, metode en doelwit (Mouton 1987:88):

\begin{tabular}{|l|l|l|l|}
\hline Kolon & $\begin{array}{l}\text { God se hande- } \\
\text { ling of seëning } \\
\text { (in Christus) }\end{array}$ & $\begin{array}{l}\text { God se metode } \\
\text { (in Christus) }\end{array}$ & $\begin{array}{l}\text { God se doel } \\
\text { (in Christus) }\end{array}$ \\
\hline 1 & Uitverkiesing & $\begin{array}{l}\text { "soos Hy ons in Hom } \\
\text { uitverkies het" (v 4) } \\
\text { "deurdat Hy ons heilig en } \\
\text { voorbeskik het om ons } \\
\text { as sy kinders vir } \\
\text { Homself aan te neem } \\
\text { seur Jesus Christus" (v } \\
\text { 5) }\end{array}$ & $\begin{array}{l}\text { Hom in liefde te } \\
\text { wees" (v 4) } \\
\text { "tot lof van die } \\
\text { heerlikheid van sy } \\
\text { genade" (v 6) }\end{array}$ \\
\hline 2 & Verlossing & $\begin{array}{l}\text { "In Hom het ons die } \\
\text { verlossing deur sy } \\
\text { bloed" (v 7) } \\
\text { "deurdat Hy aan ons die } \\
\text { verborgenheid van sy wil } \\
\text { bekend gemaak het (v 9) }\end{array}$ & $\begin{array}{l}\text { "met die doel om } \\
\text { hoof in Christus te } \\
\text { verenig" (v 10) }\end{array}$ \\
\hline 3 & Erflating & $\begin{array}{l}\text { "in Hom in wie ons ook } \\
\text { 'n erfdeel ontvang het" } \\
\text { (v 11) } \\
\text { "in wie julle...verseël is } \\
\text { met die Heilige Gees" (v } \\
\text { 13) }\end{array}$ & $\begin{array}{l}\text { "sodat ons kan } \\
\text { wees tot lof van sy } \\
\text { heerlikheid" (v 12) }\end{array}$ \\
\hline heerlikheid" (v 14) \\
\hline 4
\end{tabular}

God se seëninge, metode en doelwit kan na fynere ontleding ook in terme van God se motivering en tydsbepaling uiteengesit word (Mouton 1987:88). 


\begin{tabular}{|l|l|l|l|}
\hline Kolon & God se seëning & $\begin{array}{l}\text { Motivering } \\
\text { "na die welbehae van sy } \\
\text { wil" (v 5) }\end{array}$ & $\begin{array}{l}\text { Tydsbepaling } \\
\text { "voor die grond- } \\
\text { legging van die } \\
\text { wêreld" (v 4) }\end{array}$ \\
\hline 2 & Verlossing & $\begin{array}{l}\text { "na die rykdom van sy } \\
\text { genade" (v 7) } \\
\text { "Nam die volheid } \\
\text { van die tye te reël" } \\
\text { (v 10) }\end{array}$ \\
\hline 3 & Erflating & $\begin{array}{l}\text { "Ooreenkomstig (v 9) die } \\
\text { voorneme van Hom wat } \\
\text { alles werk volgens die } \\
\text { raad van sy wil" (v 11) }\end{array}$ & $\begin{array}{l}\text { vore daartoe ver- } \\
\text { ordineer is (v 11) }\end{array}$ \\
\hline 4 & $\begin{array}{l}\text { ". die Heilige Gees } \\
\ldots \text { wat die onderpand is } \\
\text { van ons erfdeel" (v 14 - } \\
\text { versekering) }\end{array}$ & $\begin{array}{l}\text { "om sy eiendom te } \\
\text { verlos" (v 14 - } \\
\text { toekomsbepaling) }\end{array}$ \\
\hline
\end{tabular}

Dit is opvallend dat nie net die gedagte van verseëling nie, maar ook aspekte van erflating/erfdeel en onderpand hier sterk figureer.

\subsection{Trinitariese gerigtheid}

In Efesiërs 1:3-14 word God Drie-enig as die Inisiatiefnemer geopenbaar in die gebeure wat vermeld word. Die oorheersende rol wat God volgens Paulus se beeldende beskrywing inneem, is dié van 'n genadige Vader wat die gelowiges seën, uitverkies, voorbeskik tot aanneming as sy kinders, hulle verlos, vergewe, die verborgenheid van sy wil aan hulle bekend maak, die volheid van die tye reël, hulle laat erf, en met die Heilige Gees verseël (Mouton 1987:140-141). Jesus Christus speel in dié gedeelte uiteraard die rol van Middelaar. Paulus gebruik die name Christus, Here en Verlosser om Jesus se bemiddelende rol en status mee te beskryf. Alles wat die Vader vooraf besluit het, word "in Hom" tot uitvoering gebring. In Efesiërs 1:3-14 lees ons agt keer van "in Christus", "in Hom", "in die Geliefde".

- Vers 3:

- Vers 4:

- Vers 6:

- Vers 7:

- Vers 10:

- Vers 11:

- Vers 13: "in Christus" "in Hom"

- Vers 13:

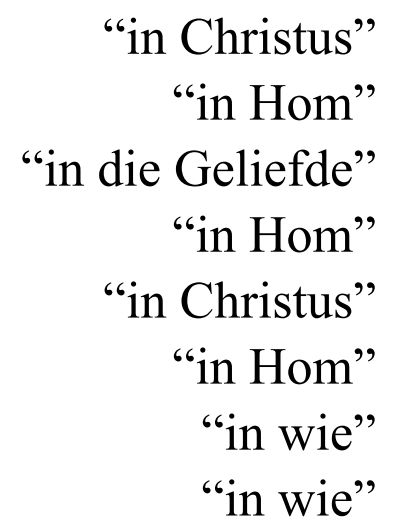


Die verseëling word hier twee maal in verband met "in Hom" genoem. Die verseëling met die Heilige Gees is dus altyd ' $n$ verseëling in Christus. In vers 13 lees ons ook twee maal van "in wie julle":

- “...in wie julle ook, nadat julle die woord van die waarheid, die evangelie van julle redding, gehoor het, verseël is met die Heilige Gees";

- “...in wie julle, nadat julle ook geglo het, verseël is met die Heilige Gees van die belofte".

Christus se Middelaarswerk strek tot by die uiterste grens waar Hy sy bloed gee om die mens te verlos (v 7): "We moeten goed tot ons laten doordringen wat dit vir ons onderwerp inhou. Het betekent, dat we over de verzegeling niet kunnen spreken los van Christus, buiten Hem" (Van't Spijker 1989:386). Die rol van die derde Persoon in die Goddelike Drie-eenheid, die Heilige Gees, word ook hier metafories beskryf as dié van 'n onderpand of waarborg. In Christus verseël God die gelowiges met die Heilige Gees. Die gelowiges uit die heidene is verseël met die Heilige Gees van die belofte. Dit is die Gees wat beloof is as gawe van die eindtyd (Floor 1995:65).

\subsubsection{Gehoor, geglo, verseël}

In die slotgedeelte van die perikoop (vv 13 en 14) word gehandel oor die verseëlende genade deur die werk van die Heilige Gees. Hier kom egter ander dimensies as in 2 Korintiërs 1:21-22 aan die orde. In vers 13 is naamlik sprake van twee gelykwaardige frases: "die woord van die waarheid" en "die evangelie van julle redding". Die boodskap van dié twee frases is dat "the true word is the gospel which saves you" (Bhae 2000:63). Die eerste deel van vers 13 impliseer dat hulle die evangelie gehoor het (Best, 1998:149) en die tweede deel van die vers bevestig dat hulle die evangelie geglo het. Die logiese gevolg in die derde deel van die vers is dat hulle verseël is met die Heilige Gees van die belofte. In hierdie verse is dus sprake van drie handelinge:

- Gehoor het:

vers $13 a$

- Geglo het: vers $13 b$

- Verseël: vers $13 \mathrm{c}$

Hierna word die posisie van die Heilige Gees nader aangedui as "die Heilige Gees van die belofte wat die onderpand is van ons erfdeel" (v 13d-14a). 
As Paulus dan nou in vers 13 die term verseël gebruik, dan word benadruk dat God die eienaarskap ten opsigte van sy kinders bekragtig en dat Hy die versekering van sy liefde en versorging vir hulle waarborg (Mouton 1987:139). Verseëling word hier ook gebruik in die sin van 'n gesaghebbende persoon (God) wat sy merk (seël) aanbring op sy verseëldes. Die verseëling kon ook dien as beskerming teen enige beskadiging of vervalsing van 'n dokument (Rienecker 1980:522). Uit die konteks van 1:3-14 blyk dit dat die Heilige Gees God se teken aan die gelowiges is - 'n teken waarmee Hy hulle as sy ware eiendom gemerk het. Reymond (1998:762.) merk in hierdie verband op:

"The Spirit of God's Son, who is also the Spirit of adoption, not only testifies with Christians' spirits that they are children of God but also, as the guaranteeing pledges, of their inheritance (note here the legal sonship terminology), seals them as God's own possession to the day of eschatological redemption (Eph 4:30; 2 Cor 5:5)".

Van hierdie erfenis is die Heilige Gees die eerste paaiement.

\section{Bevinding vir die kategese}

Verseëling deur die Heilige Gees word verbind met die hoor van die evangelie; die geloof in wat gehoor is, impliseer ten diepste dit wat van God gehoor is.

\subsection{Geloof en verseëling}

Belangrike vrae wat vanuit bogenoemde beredenering na vore kom, is die volgende: Vind geloof en verseëling gelyktydig plaas? Op watter tydstip word die verseëling met die Heilige Gees 'n werklikheid? Een groep vertalings van Efesiërs 1:13-14 dui 'n sekere tyd aan met die bepaling "nadat"; ander het dit bloot vertaal met "toe".

Wat in hierdie verband vasgestel moet word, is wat die tydsaanduiding aoristus ("nadat julle geglo het") inhou? Die twee werkwoorde glo en verseël moet hier beskou word as die twee kante van een en dieselfde saak. Die volgorde is: eers kom tot die geloof en dan die verseëling met die Heilige Gees van die belofte. Die verseëling met die Heilige Gees verskil in wese nie van die doop met die Heilige Gees of die wedergeboorte nie. Deur die doop met die Heilige Gees of die wedergeboorte as 'n verseëling met die Heilige Gees aan te dui, word net 'n bepaalde aspek van die werk van die 
Heilige Gees in die gelowige tot uitdrukking gebring, naamlik die waarborgaspek en die aspek van 'n veilige bestemming (Floor 1979:84). Op dié wyse word die hele gedagte van eiendomsreg beklemtoon.

Van't Spijker (1989:403) toon ook aan dat die nadat in vers 13 nie in 'n temporele, tydelike sin, verstaan moet word nie, naamlik eers nadat die mens tot geloof gekom het - moontlik 'n geruime tyd daarna - is daar sprake van die verseëling met die Heilige Gees nie. Die geloof is die middel waardeur die gelowige die eiendomstempel van die Heilige Gees ontvang. Die verseëling met die Heilige Gees geskied deur die geloof: "Die geloof is dus uit die gehoor, en die gehoor is deur die woord van God" (Rom 10:17). Waar die geloof kom, sit God sy seël van die Heilige Gees in die hart; daar plaas Hy self sy eiendomsbewys. Efesiërs 1:13 leer dat die geloof direk lei tot die verseëling met die Heilige Gees.

Ook die omgekeerde is waar. Net die Heilige Gees alleen leer ons om te glo. Die geloof is 'n gawe van die Heilige Gees. Ons ontvang die Heilige Gees, dit wil sê die lewe van God - nie op grond van die werke van die wet nie - maar op grond van die prediking van die geloof (Ef 2:8). En deur die geloof word 'n mens verseël met die Heilige Gees. Die seël is die Heilige Gees en hierdie seël word nie ontvang waar geloof nie alreeds is nie. As daar nie geloof is nie, word die Heilige Gees ook nie as seël ontvang nie.

\subsubsection{Verseëling word duidelik in geloofswerke}

In Efesiërs 4:30 noem Paulus nogmaals die verseëling met die Heilige Gees, maar in 'n ander verband as in 2 Korintiërs 1:21-22. "En moenie die Heilige Gees van God bedroef nie deur wie julle verseël is tot die dag van verlossing." Die indikatief van die verseël word hier verbind aan die imperatief om nie die Heilige Gees te bedroef nie. Letterlik staan daar: Hou op om die Heilige Gees te bedroef. Moontlik dink die apostel aan die gawes wat die gemeente, wat tot die geloof gekom het, alles van God ontvang het. Die volgende gawes is vanuit wyer konteks ter sprake:

- $\quad$ Gelowige gebedstoegang tot die Vader (2:18).

- Die saamgevoeg word tot een woonplek van God (2:22), in eenheid van die Heilige Gees (4:3), ondersteun deur apostels, profete, herders en leraars (4:11 v.v.). 
- Die openbaring aan apostels en profete oor die medeerfgenaam-wees van die heidene (3:5-6).

- Die versterking van die inwendige mens met as gevolg toenemende kennis van die liefde van Christus (3:16; 4:23).

- Die onderlinge spreke met psalms, lofsange en geestelike liedere (5:18-20).

- $\quad$ Die saambid vir alle heiliges (6:18).

Dit is aan die Gees van Christus te danke dat die gawes vir die geestelike lewe in allerlei vorme bestaan. En juis daarom die opdrag in 5:30: "moet die Heilige Gees nie bedroef nie". Bedroef kan hier gesien word in die sin van die teenpool van die toe-eien van die lewe in Christus en van die gawes van die Gees soos hierbo aangedui. Wie nie toe-eien nie, verval - gesien vanuit die teksverband waarin 5:30 staan - in leuens, woede, bitterheid, haat: die werke van die sondige natuur en nie van verseëldes deur die Heilige Gees nie.

\subsubsection{Samevatting van resultate uit Efesiërs 1:3-13}

- Die gedagte van verseëling bevestig in Efesiërs 1:13-14 en in 4:30, soos ook in 2 Korintiërs 1:21-22, dat die gelowige deur die Heilige Gees gemerk is as eiendom van God. Die gelowige het voortdurende sekuriteit. Die daad van bevestiging is onveranderlik, en die een wees met Christus neem steeds toe.

- Die Heilige Gees as onderpand/waarborg verwys na die betaling van die eerste paaiement van die beloofde verlossing wat God in die harte van sy gelowige kinders gegee het. Die Heilige Gees waarborg dat God sy kinders gesalf en verseël het.

- In Efesiërs 1:13-14 val die nadruk op verseël met die Gees van die belofte. Verseëling en geloof staan nie los van mekaar nie, maar is onlosmaaklik verbind.

- Die verseëling met die Heilige Gees word 'n werklikheid wanneer iemand tot geloof kom. Dit vind gelyktydig plaas en is as't ware twee kante van dieselfde saak. Daar is 'n onmiddellike relasie tussen geloof en verseëling.

- Ook is daar 'n oorsaaklike verband tussen die gepredikte Woord van God wat ons hoor en geloof en verseëling. Die Woord dien as medium om sowel die geloof as die verseëling met die Heilige Gees aan ons te skenk. 
- Waar die geloof aanwesig is, daar plaas God sy seël van die Heilige Gees in die hart. Waar geloof teenwoordig is, daar plaas God self sy eiendomsbewys.

- Wie die Heilige Gees voortdurend bedroef, bewys dat hy die werk van Christus nie vir homself toegeëien het nie.

\section{KONKRETISERENDE RIGLYNE VIR DIE KERKLIKE KATEGESE}

In die inleiding van die artikel is gestel dat die doel is om basisteoretiese gegewens te ontgin oor die verseëling deur die Heilige Gees en verwante begrippe wat saam met verseël gebruik word. Toepaslike bevindinge vir die kategese is telkens na bepaalde verkennings gebied. Die feit dat hierdie ondersoek veral die klem op basisteoretiese elemente laat val, hou in dat in hierdie artikel nie aandag gegee (kan) word aan metateoretiese en praktykteoretiese sake nie, hoewel data uit die Sielkunde, Opvoedkunde en Kommunikasiekunde waardevolle perspektiewe sou kon bied. Daarom sal hier volstaan moet word met die volgende konkretiserende perspektiewe van die basisteoretiese werk wat gedoen is:

- Die feit dat ons verseël is deur die Heilige Gees as God se eiendomsbewys, dat ons veilig bewaar word en verseker is van die volle toekomstige heerlikheid moet in die kategetiese proses gerig word op persoonlike toeëiening. Daarom ook behoort die katkisant hierdie toeëiening uit te leef in opregte, konkrete dade van geloof

- $\quad$ Verseëling deur die Heilige Gees, as bewys van die vastigheid en sekerheid van God se beloftes, behoort die vertrekpunt te wees in kategese

- Die aksie van die verseëling deur die Heilige Gees moet in kerklike kategese konkreet, in beeldende taal wat op die verstaansvlak van die katkisant is, aangebied word.

- Die betekenis van die verseëling deur die Heilige Gees behoort 'n vaste refrein te wees deur die verskillende dimensies van die kerklike kategese heen. In die kurrikulering, leerplanne, lesgidse en aanbieding in die klas moet hierdie aspek voortdurend herhaal word.

- Dwarsdeur die kategese, maar veral tydens die gesprekke in die ondersoek van belydeniskatkisante, behoort die vraag na die feit en konkrete vrugte van die verseëling deur die Heilige Gees in die jongmense se lewe 'n prominente plek in te neem. 
- $\quad$ Die vrug van die verseëling deur die Heilige Gees moet in die lewe van die katkisant en in sy optrede duidelik na vore te kom. Iemand kan nie slaag as katkisant en druip in geloofsekerheid nie.

\section{Literatuurverwysings}

An, J S 2001. Creative Bible teaching to young children. Unpublished Ph.D. thesis, Potchefstroomse Universiteit vir CHO.

Andrews, E H 1982. The promise of the Spirit. Hertfortshire: Evangelical Press.

Best, E 1998. (ICC) Ephesians. Edinburgh: Clark.

Bhae, J Y 2000. The subject of the letter to the Ephesians. A thought-mapping approach. Unpublished Ph.D thesis, Potchefstroomse Universiteit vir $\mathrm{CHO}$.

Bruner, F D 1970. A theology of the Holy Spirit. Grand Rapids: Eerdmans.

Campbell-Lane, Y 2003. Inner change: A pastoral-theological study. Unpublished Ph.D thesis, Northwest-University, Potchefstroom Campus.

Dreyer, T F 2003. Die rol van die gemeente as 'n gemeenskap van gelowiges in begeleiding tot belydenisaflegging. Ongepubliseerde M.Th-skripsie, Potchefstroomse Universiteit vir CHO.

Floor, L 1979. Hy wat met die Heilige Gees doop. Pretoria: NG Kerkboekhandel.

-, 1995. Efesiërs. Een in Christus. Kampen: Kok.

Garland, D E 1999 An exegetical and theological exposition of Holy Scripture. 2 Corinthians (The new American commentary). Nashville: Broadman.

Huey, F B 1975. S v Seal, in: Merrill, C T \& Steven, B. The Zondervan pictorial encyclopedia of the Bible. Vol. 5, 319-324. Grand Rapids: Eerdmans.

Lotter, G A 1993. Die werk van die Heilige Gees in die gelowige volgens 2 Korintiërs. Ongepubliseerde Th.D-proefskrif, Potchefstroomse Universiteit vir CHO.

Louw, J P \& Nida, E A 1998a. Greek-English lexicon of the New-Testament based on semantic domains. Vol I. Roggebaai: Bible Society of South Africa.

-, 1988b. Greek-English lexicon of the New-Testament based on semantic domains. Vol 2. Roggebaai: Bible Society of South Africa.

Mouton, A E J 1987. ' $n$ Eksegeties-hermeneutiese verkenning van die Christooi-kernbelydenis by Paulus na aanleiding van Efesiërs 1:13-14. Ongepubliseerde M.A.-verhandeling, Universiteit van Port Elizabeth.

Muddiman, J 2001. The epistle to the Ephesians. London: Continuum.

Prins, J M G 2001. Geloofsoortuigings, -ervarings en -gedrag van kerklik betrokke tieners - verslag van 'n empiriese ondersoek, NGTT 41(1\&2),1334. 
Reymond, R L 1998. A new systematic theology of the Christian faith. Nashville: Nelson.

Rienecker, F 1980. A linguistic key to the Greek New Testament. Grand Rapids: Zondervan.

Song, M H 1998. Pauline pneumatology. The new life through the Spirit in the four major letters of Paul. Unpublished Th.D thesis, Potchefstroomse Universiteit vir $\mathrm{CHO}$.

Thrall, M E 2000. 2 Corinthians (International critical commentary) Edinburgh: Clark

Van't Spijker, W 1989. De verzegeling met de Heilige Geest, De Wekker, 98(42), 365-367.

Van der Merwe, C N 2004. Kategese as middel tot heilsekerheid en heilstoeeiening in konteks van die verbond en die koninkryk. Ongepubliseerde Ph.D-proefskrif, Noordwes-Universiteit, Potchefstroomkampus.

Winslow, O 1984. The work of the Holy Spirit. Edinburgh: Banner of Truth. 